\title{
Effects of Water Temperature, Turbidity, and Rainbow Trout on Humpback Chub Population Dynamics
}

Umpback chub (Gila cypha Miller 1946), found only in the Colorado River Basin, was one of the first species to
be given full protection under the Endangered Species Act of 1973 . Habitat alterations, such as changes in flow
and water temperature caused by dams, and the introduction of nonnative fish have contributed to population declines
in humpback chub and other native fish. These habitat alterations provide ideal conditions for the nonnative sport fish,
rainbow trout (Oncorhynchus mykiss Walbaum 1792). Managers have long sought to balance recovery of humpback chub
with a viable rainbow trout fishery. However, finding this balance requires understanding how environmental conditions
and rainbow trout have affected humpback chub populations. Recent findings indicate that the Colorado River can be
managed for rainbow trout while maintaining a healthy humpback chub population in Grand Canyon National Park.

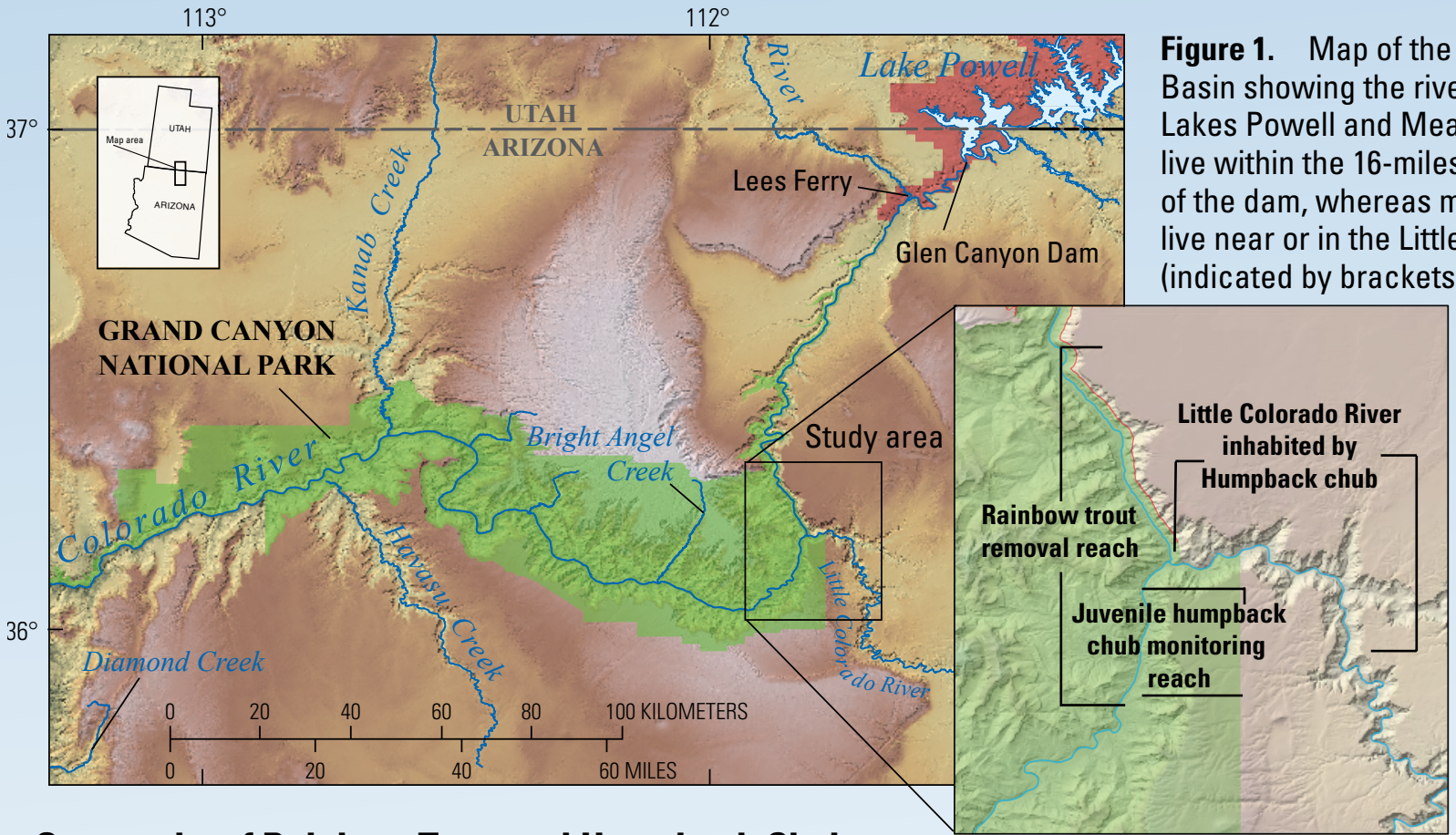

\section{Geography of Rainbow Trout and Humpback Chub Primary Populations}

Rainbow trout and humpback chub can be found throughout most of the Colorado River between Glen Canyon Dam and Lake Mead (fig. 1). However, most rainbow trout live in the Lees Ferry reach - a 16-mile (26 $\mathrm{km})$ segment directly downstream of Glen Canyon Dam. Conversely, most of the humpback chub are found 78

miles $(125 \mathrm{~km})$ downstream of the dam, near the confluence of the Little Colorado and Colorado Rivers and in the lower 8.5 miles $(13.5 \mathrm{~km})$ of the Little Colorado River (fig. 1). This reach of the river is the primary humpback chub rearing area in Grand Canyon National Park and home to the majority of humpback chub in the entire Colorado River Basin. This population is the focus of the studies summarized here, although there is an increasing 
population found in western Grand Canyon National Park.

Between 2011 and 2016, rainbow trout and humpback chub populations were extensively sampled during 29 research trips, and captured fish were marked with unique identifier tags (figs. 2 and 3). Recapture data allowed scientists to estimate growth, survival, and movement for both species and improved understanding of species' interactions. These studies revealed that the vast majority of adult rainbow trout found near the confluence of the Little Colorado and Colorado Rivers emigrated from upstream, even though most rainbow trout only move short distances (Korman and others, 2015). If rainbow trout abundance is high at Lees Ferry, even a small percent migrating downstream could have negative effects on the humpback chub population living in and near the Little Colorado River.

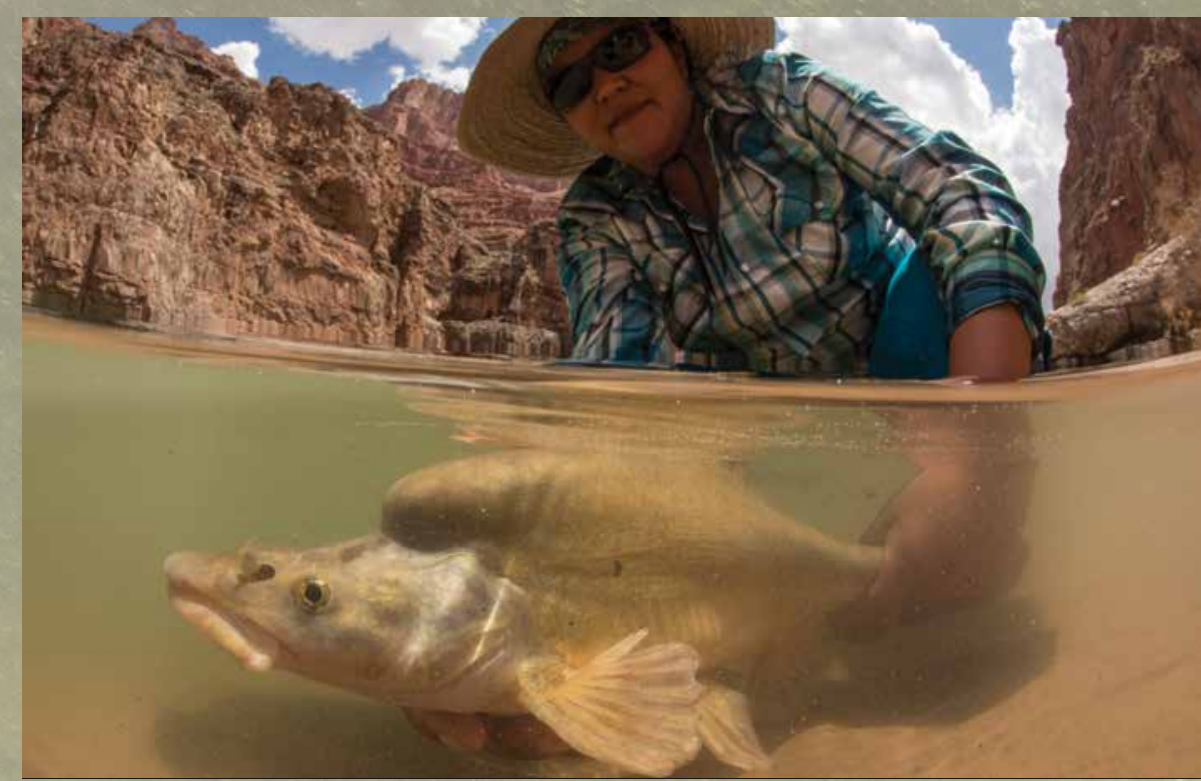

Figure 2. Photograph looking upstream to Steph Jackson (river guide with Grand Canyon Youth) holding a humpback chub along the shore of the Colorado River in eastern Grand Canyon National Park, 78 miles downstream from Glen Canyon Dam. Copyrighted photograph by Freshwaters Illustrated. Used with permission.

\section{Rainbow Trout and Humpback Chub Interactions}

Rainbow trout thrive in the cold, clear waters created by the Glen Canyon Dam. Rainbow trout compete with humpback chub for food and habitat and eat juvenile humpback chub. Because of this, rainbow trout were hypothesized to be a primary cause of humpback chub decline. However, the introduction of rainbow trout to the Colorado River occurred in parallel with changes in environmental conditions (decreases in seasonal variation in temperatures and lower sediment load) associated with the completion of Glen Canyon Dam and filling of Lake Powell between 1963-1980. This makes it difficult to identify the factors that led to humpback chub decline. For example, localized rainbow trout removals near the confluence of the Colorado and Little Colorado Rivers and a system-wide decline in trout abundance in the mid-2000s coincided with warmer summer and fall water temperatures. When the number of humpback chub adults increased some years later, it was difficult to isolate the relative importance of the trout removal from unexpected river warming.

The U.S. Geological Survey Grand Canyon Monitoring and Research Center (GCMRC) and cooperating scientists studied the population dynamics of rainbow trout and humpback chub to better understand these interactions. Recently, researchers have developed new methods to directly study the early life stages of humpback chub, allowing them to determine the relative importance of rainbow trout and environmental conditions on humpback chub growth and survival. Scientists also identified other factors that may influence humpback chub population dynamics. This information was used to identify costeffective methods to manage rainbow trout in terms of their effects on humpback chub populations.

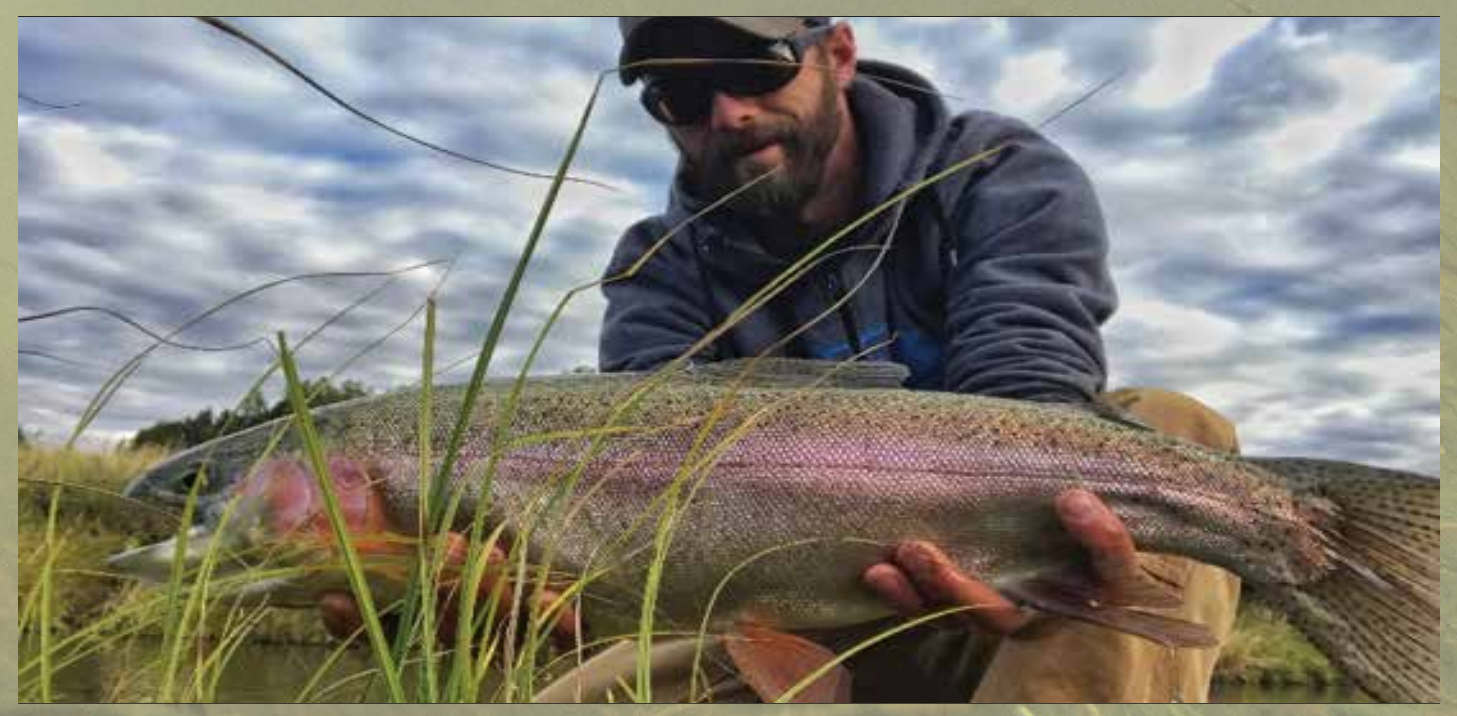

Figure 3. Photograph of a rainbow trout, which are not native to the Colorado River Basin, but are valued for recreational and cultural reasons. U.S. Geological Survey Photograph by Morgan Ford. 


\section{Environmental Factors Affecting Humpback Chub}

By combining population data from both species, GCMRC and collaborating scientists developed statistical models that measured the effects of rainbow trout population size, water temperature, and turbidity (cloudiness) on humpback chub survival, growth, and estimated population size (Yackulic and others, 2018). As hypothesized, rainbow trout had a negative effect on survival of juvenile humpback chub and temperature had a positive effect on their growth (fig. 4). Growing quickly helps humpback chub reach sizes at which they are no longer vulnerable to rainbow trout predation. Taken together, the positive effect of temperature was equal to, and sometimes greater, in magnitude than the negative effects of rainbow trout. Turbidity also had a strong positive effect on growth of humpback chub, but a negative effect on their survival. Studies of rainbow trout diets show that they prey on juvenile humpback chub at higher rates when the turbidity is higher.

Figure 4. Diagram showing the effects of rainbow trout, water temperature, and turbidity (water cloudiness) on the survival, growth, and estimated population size of the endangered humpback chub. Blue circles indicate a positive effect, red circles indicate a negative effect, and yellow circles indicate no or minimal effect. The diameter of the red and blue circles indicate the relative magnitude of the effect.

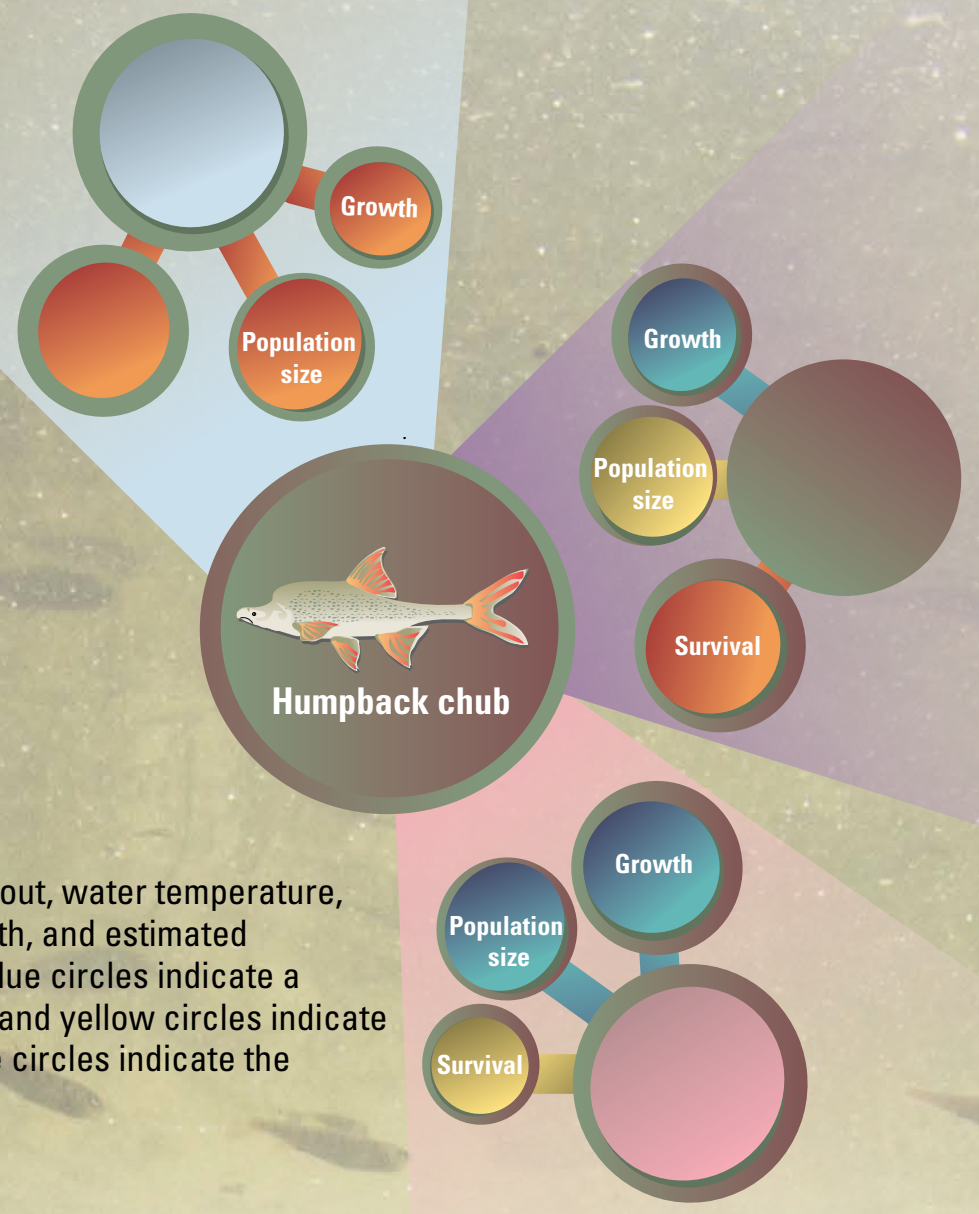

\section{Cost-Effective Management of Rainbow Trout}

Rainbow trout are valued for various reasons in Glen Canyon National Recreation Area and Grand Canyon National Park. For example, a recreational fishery, worth an estimated \$2.6 million annually (Bair and others, 2016), exists in Glen Canyon. In addition, some stakeholders have strong interest in preserving all life in the Grand Canyon. However, as a federally listed endangered species, humpback chub must legally be protected. To balance stakeholder concerns and the species' protection, it is important to determine whether removals are necessary to meet recovery goals and how limited removals might be designed to maximize benefits to humpback chub.

One of the tools that managers utilize to protect humpback chub is to kill and remove rainbow trout and other nonnative fish outside of the tailwater fishery. Removal efforts have focused on the trout removal reach, a 9.5mile $(15 \mathrm{~km})$ section centered around the Little Colorado River confluence (fig. 1), which is the primary location for humpback chub spawning and rearing. Several Native American Tribes consider this area to be sacred and object to these removals. Additionally, because the area is remote, removals are costly. Therefore, maintaining humpback chub abundance while minimizing the number of nonnative fish removals is ideal.

Researchers developed a computer model based on biological interactions of the rainbow trout and humpback chub and economic considerations (a bioeconomic model) to address this issue (Donovan and others, 2019). Using data from both species, scientists were able to determine the fewest number of removal events required to maintain a viable humpback chub population under various conditions. The bioeconomic model can inform managers about the cost-effectiveness of removals given the population levels

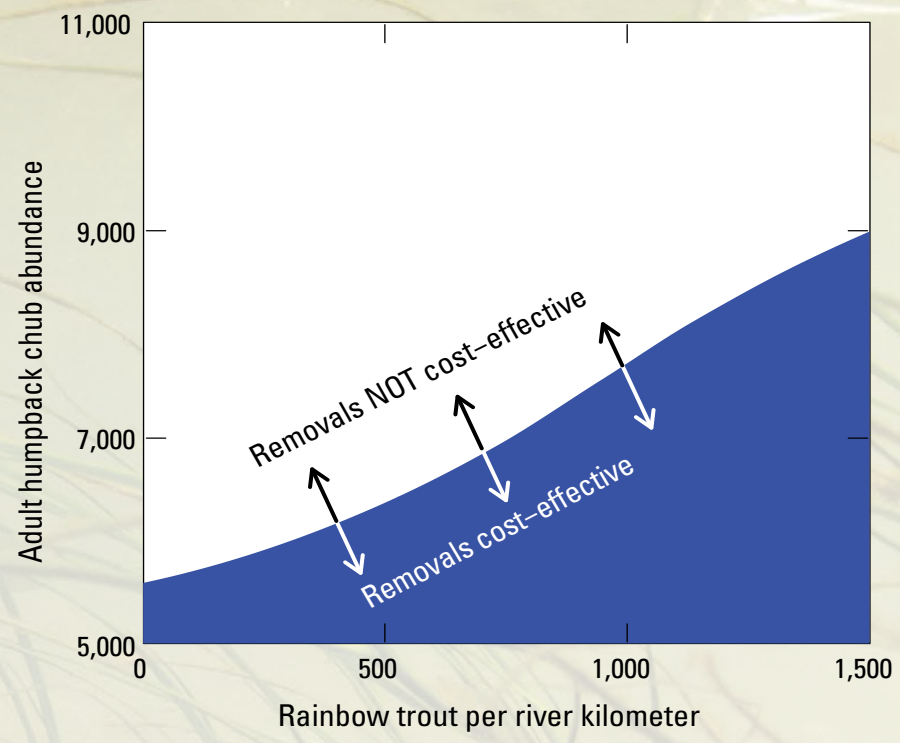

Figure 5. Figure illustrating how the size of both adult humpback chub and rainbow trout populations determines when rainbow trout removals are a cost-effective management strategy. Humpback chub population numbers are for the population located near the confluence of the Colorado and Little Colorado Rivers. Adult rainbow trout numbers are based on densities in the Colorado River just downriver from the Little Colorado River. 
of both humpback chub and rainbow trout (fig. 5). The model also suggests that if humpback chub adult abundance is below 6,000 and rainbow trout abundances are above $1,100 \mathrm{fish} / \mathrm{km}$, then even the maximum number of six removals per year would not be sufficient to confidently avoid a likely decline to 5,000 or less adult humpback chub in Grand Canyon National Park. Under those conditions, additional methods of managing rainbow trout or water temperature would be needed for humpback chub populations to remain viable. After dipping to a low of about 6,000 individuals, this population has stabilized at about 12,000 since 2009 . The population of adult humpback chub in and near the Little Colorado River is large enough (about 12,000), as of 2019, that removals are not currently needed under any modeled rainbow trout abundance.

\section{Summary and Looking Ahead}

Rainbow trout negatively impact humpback chub population, however, environmental conditions (for example, turbidity and temperatures) may play an even more important role in long-term population trends of humpback chub. Using data collected from 29 sampling trips over 5 years, USGS and cooperating scientists were able to identify dispersal patterns of rainbow trout downstream of Glen Canyon Dam and the effects of rainbow trout, water temperature, and turbidity on humpback chub populations. Environmental conditions of the river had equal or greater effects on humpback chub population dynamics than rainbow trout.

Cover. Photograph showing the confluence of the muddy Paria River (left) and the clear Colorado River (right) near Lees Ferry, 16 kilometers southwest of the Glen Canyon Dam. Copyrighted photograph by Freshwaters Illustrated. Used with permission.

Back. Glen Canyon Dam impounding the waters of the Colorado River above Grand Canyon National Park. U.S. Geological Survey Photograph by Todd Wojtowicz.

Banner and inside spread. Photograph showing multiple juvenile rainbow trout among macrophytes (aquatic plants) at Lees Ferry, a segment of the Colorado River 16 kilometers southwest of the Glen Canyon Dam. Copyrighted photograph by Freshwaters Illustrated. Used with permission.
Other factors currently under investigation may also play an important role in humpback chub population dynamics. Brown trout (Salmo trutta Linnaeus 1758) were also introduced to the Colorado River and are known to have higher per capita effects on humpback chub than rainbow trout. Food availability is also an important factor in the sustainability of humpback chub populations. Understanding how other factors may affect humpback chub will be important to maintaining a viable population of this endangered species and will improve the ability to make informed management decisions. Managing for the stabilization or increase of endangered humpback chub populations while maintaining nonnative rainbow trout in Glen Canyon requires continual monitoring of populations of both species and adaptive management of these and other Colorado River resources.

\section{References}

Bair, L.S., Rogowski, D.L., and Neher, C., 2016, Economic value of angling on the Colorado River at Lees Ferry; using secondary data to estimate the influence of seasonality: North American Journal of Fisheries Management, v. 36, no. 6, p. 1229-1239.

Donovan, P., Bair, L.S., Yackulic, C.B., and Springborn, M.R., 2019, Safety in numbers; cost-effective endangered species management for viable populations: Land Economics, v. 95, no. 3, p. 435-453.

Korman, J., Yard, M.D., and Yackulic, C.B., 2015, Factors controlling the abundance of rainbow trout in the Colorado River in Grand Canyon in a reach utilized by endangered humpback chub: Canadian Journal of Fisheries and Aquatic Sciences, v. 73, no. 1, p. 105-124.

Yackulic, C.B., Korman, J., Yard, M.D., and Dzul, M., 2018, Inferring species interactions through joint markrecapture analysis: Ecology, v. 99, no. 4, p. 812-821.

Authors: Charles B. Yackulic and Julia B. Hull Edited by Phil Frederick

Layout and design by Kimber Petersen and Katie Sullivan For more information contact:

Charles B. Yackulic: cyackulic@usgs.gov

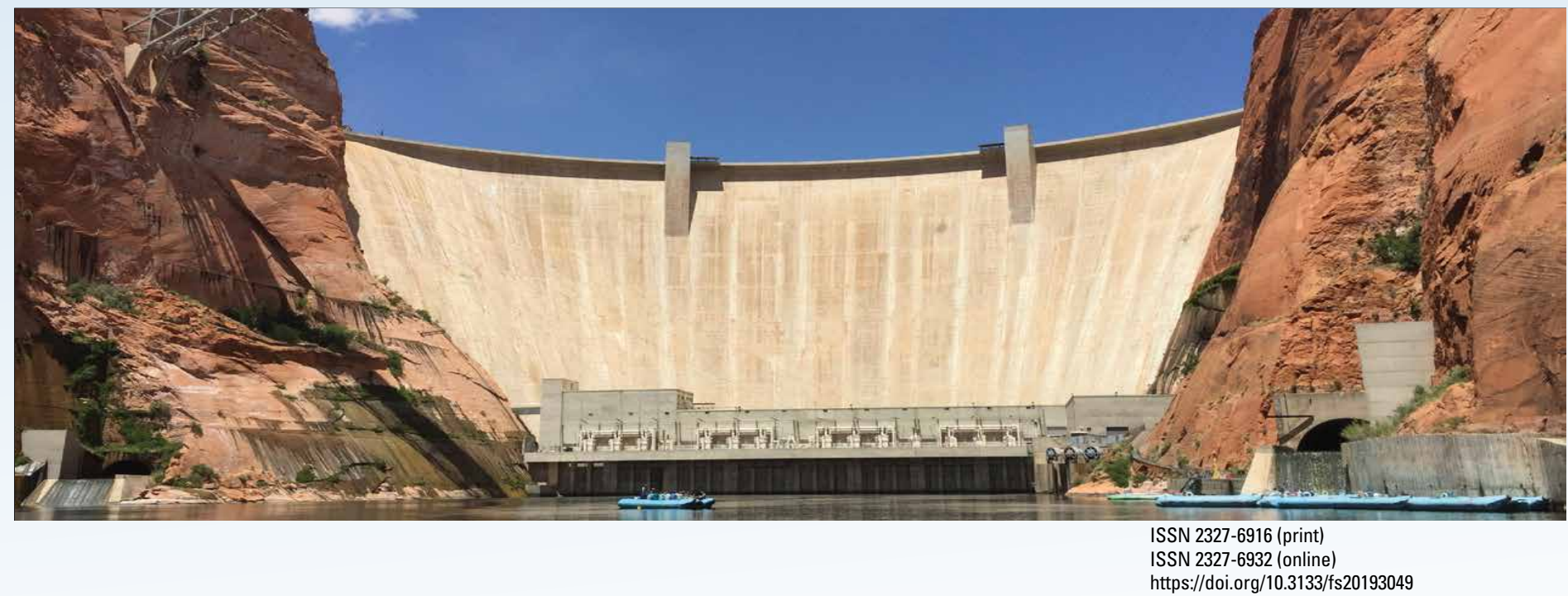

